\title{
Stable Expression of Angiopoietin-1 and Other Markers by Cultured Pericytes: Phenotypic Similarities to a Subpopulation of Cells in Maturing Vessels During Later Stages of Angiogenesis In Vivo
}

\author{
Christian Sundberg, Marcin Kowanetz, Lawrence F. Brown, Michael Detmar, \\ and Harold F. Dvorak
}

\begin{abstract}
Department of Pathology (CS, LFB, HFD), Beth Israel Deaconess Medical Center and Harvard Medical School, and Department of Dermatology (MD), Massachusetts General Hospital, Boston, Massachusetts, and Department of Medical Biochemistry and Microbiology (CS, MK), Biomedical Center and Uppsala University, Uppsala, Sweden
\end{abstract}

SUMMARY: Pericytes have been difficult cells to study because they do not maintain their characteristic phenotype in vitro, and they begin to express fibroblast markers after only a few days in culture. We now report methods for the isolation, purification, culture, and repurification of human dermal pericytes from mixed cell populations using an immunoaffinity-magnetic bead approach coupled with the 3G5 IgM monoclonal antibody that is specific for a pericyte surface ganglioside. These purified cells could be expanded in culture, and they maintained their pericyte phenotype for up to 8 days. In addition, they strongly expressed angiopoietin-1 (Ang-1) but not angiopoietin-2, Tie-1, or Tie-2; in contrast, dermal microvascular endothelial cells exhibited a reciprocal expression pattern. These findings are important because the close proximity of endothelial cells and pericytes has often made it difficult to determine with certainty the specific cell type(s) that expressed each of these proteins in situ. Extending our in vitro findings to two models of angiogenesis in vivo, we demonstrated a subpopulation of Ang-1-expressing cells that appeared in maturing microvessels during later stages of cutaneous wound healing and vascular permeability factor/vascular endothelial growth factor-induced angiogenesis. Our results provide strong evidence that Ang-1 is expressed by pericytes in vitro and in vivo and that the role proposed for Ang-1 in vessel maturation in development can be extended to vessel maturation after angiogenesis in adult tissues. (Lab Invest 2002, 82:387-401).

$M$ ature blood vessels are comprised of lining endothelial cells and one or more enveloping layers of supporting cells; in arteries and veins, these supporting cells are smooth muscle cells, whereas in capillaries and venules they are termed pericytes (Rhodin, 1980). The earliest blood vessels formed in the embryo consist entirely of endothelial cells, and recruitment of supporting pericytes is believed to be essential for vessel survival, maturation, and stability (Benjamin et al, 1998; D’Amore, 1992; Yancopoulos et al, 2000). Pericytes have also been implicated in angiogenesis, the process by which new blood vessels develop from preexisting vessels in response to angiogenic cytokines such as vascular permeability factor/vascular endothelial growth factor (VPF/VEGF) (Pettersson et al, 2000; Sundberg et al, 2001). Detachment of pericytes from preexisting microvessels is an

Received September 17, 2001.

This work was supported by grants from the Swedish Cancer Society, Swedish Medical Research Council, Konung Gustaf V:s 80-ärsfond (to CS), by U.S. Public Health Service Grants CA-50453 and HL-59316 (to HFD), and by NIH Grants CA69184 and CA 86410 (to MD).

Address reprint requests to: Dr. Christian Sundberg, Department of Medical Biochemistry and Microbiology, Uppsala University, BMC, Box 575, SE-751 23, Uppsala, Sweden. early feature of VPFNEGF-induced angiogenesis and leads to extensive vessel enlargement and the formation of "mother" vessels. Mother vessels subsequently differentiate along several apparently independent lines into mature, pericyte-coated, or smooth muscle cell-coated vessels of varying size and type.

Despite their recognized importance in both vasculogenesis and angiogenesis, pericytes have received less attention than endothelial cells, and their functions are only now beginning to be understood. Pericytes are thought to have roles in limiting endothelial cell proliferation (Hirschi et al, 1998; Orlidge and D'Amore, 1987) and in both vascular pruning and remodeling (Benjamin et al, 1998; Nguyen and D'Amore, 2001). Little is known as yet about the molecular events that regulate pericyte behavior. Studies in the embryo have implicated platelet-derived growth factor (PDGF) in pericyte recruitment (Lindahl et al, 1998); however, there is evidence that PDGF's role in pericyte function may differ in the adult (Crosby et al, 1999; Lindahl et al, 1998; Rajkumar et al, 1999; Reuterdahl et al, 1993; Sundberg et al, 1993, 1996, 1997). Members of the angiopoietin family have also been implicated in pericyte recruitment (Lindahl et al, 1998; Yancopoulos et al, 2000). Angiopoietins (1, 2, and 4) serve as ligands for the Tie family of receptor tyrosine kinases that are expressed on vascular endo- 
thelium. All three angiopoietins bind to the Tie-2 receptor (Davis and Yancopoulos, 1999; Gale and Yancopoulos, 1999; Yancopoulos et al, 2000).

Studies of pericyte function have been hindered because, although they can be isolated, pericytes exhibit an unstable phenotype in culture (Challier et al, 1995; D'Amore, 1992; de la Rubia et al, 1992; He and Spiro, 1995; Helmbold et al, 2001; Hoying et al, 1996; Lyons et al, 1994; Morse and Sidikaro, 1990; Sato et al, 1990; Schor et al, 1991; Schor and Schor, 1986; Shojaee et al, 1998; Wisse et al, 1996). They quickly alter their expression of several different cell typespecific markers and ultimately differentiate into collagen Type I-producing cells that have the characteristics of fibroblasts (Ivarsson et al, 1996; Sundberg et al, 1996). Studies making use of cultured "pericytes" have therefore been difficult to interpret.

The goals of the present study were as follows: (a) To develop robust methodology to isolate, purify, and culture pericytes that retained a stable phenotype consistent with that of pericytes in vivo. (b) To grow these cells in sufficient quantities for biochemical and molecular biological studies. (c) To determine whether cultured pericytes express angiopoietins or Tie receptors. (d) To determine whether the maturation role suggested for angiopoietin-1 (Ang-1) in vasculogenesis can be extended to angiogenesis as it occurs in the adult.

\section{Results}

Immunohistochemical Staining for Different Cell Type-Specific Markers in Newborn Human Foreskins

Human neonatal foreskins obtained at circumcision were analyzed for a variety of cell type-specific markers by immunohistochemistry (Table 1). Staining with antibodies to vascular markers was readily localized both to large blood vessels (defined as vessels with a multilayered muscular coat) and to small blood vessels, but, particularly in the latter, it was often not possible to distinguish staining of endothelial cells and pericytes.

As expected, antibodies to CD31 stained endothelial cells in both large and small vessels, whereas PAL-E staining was largely confined to microvascular

Table 1. Immunohistochemical Staining for Cell Type-Specific Markers in Freshly Excised Newborn Human Foreskins ${ }^{a}$

\begin{tabular}{|c|c|c|c|c|}
\hline Cell markers & $\begin{array}{l}\text { Large } \\
\text { vessels }\end{array}$ & $\begin{array}{l}\text { Micro } \\
\text { vessels }\end{array}$ & $\begin{array}{l}\text { Dermal } \\
\text { interstitial } \\
\text { cells }\end{array}$ & Epithelium \\
\hline \multicolumn{5}{|l|}{ Endothelial cells } \\
\hline CD31, DAKO (Parums et al, 1990) & & +++ & 0 & 0 \\
\hline PAL-E, Sanbios, Netherlands (Schlingemann et al, 1985) & & +++ & 0 & 0 \\
\hline \multicolumn{5}{|l|}{ Pericytes/smooth muscle cells } \\
\hline $\begin{array}{l}\text { Desmin, DAKO, } \\
\text { mAb clone D33 (Van Muijen et al, 1987) }\end{array}$ & & & 0 & 0 \\
\hline $\begin{array}{l}\text { Smooth muscle } \alpha \text {-actin, Sigma, } \\
\text { mAb clone } 1 \text { A4 (Skalli et al, 1986) }\end{array}$ & & & 0 & 0 \\
\hline $\begin{array}{l}\alpha 1 \beta 1 \text { integrin, T cell diagnostics, Woburn, Massachusetts, } \\
\text { mAb clone TS2/7 (Hemler, 1990) }\end{array}$ & + & +++ & 0 & 0 \\
\hline $\begin{array}{l}\alpha \text { and } \gamma \text {-actin, DAKO, } \\
\text { mAb clone HHF35 (Gown et al, 1986) }\end{array}$ & $0^{+}$ & $S^{+++}$ & 0 & 0 \\
\hline $\begin{array}{l}\text { Calponin, Sigma, } \\
\text { mAb clone hCP }\end{array}$ & & \pm & 0 & 0 \\
\hline $\begin{array}{l}\text { Smooth muscle myosin, Sigma, } \\
\text { mAb clone hSM-V (Longtine et al, 1985) }\end{array}$ & ++4 & + & 0 & 0 \\
\hline $\begin{array}{l}\text { HMW-MAA, Sanbios, Netherlands } \\
\text { mAb clone NKI-M6 (Natali et al, 1981) }\end{array}$ & + & 0 & 0 & 0 \\
\hline $\begin{array}{l}\text { PDGF } \beta \text {-receptor, } \\
\text { mAb Clone PDGFR- } \beta_{2} \text { (Heldin et al, 1988) }\end{array}$ & 0 & 0 & 0 & 0 \\
\hline \multicolumn{5}{|l|}{ Fibroblasts } \\
\hline $\begin{array}{l}\text { Procollagen type } 1 \text { c-propeptide, } \\
\text { Biogenesis, Sandown, New Hampshire (MacDonald et al, 1986) }\end{array}$ & 0 & 0 & 0 & 0 \\
\hline $\begin{array}{l}\text { Prolyl-4-hydroxylase, DAKO } \\
\text { mAb clone 5B5 (Höyhtyä et al, 1984) }\end{array}$ & 0 & 0 & 0 & 0 \\
\hline \multicolumn{5}{|l|}{ Pericytes and fibroblasts } \\
\hline $\begin{array}{l}\text { ASO2, Dianova, Hamburg, Germany } \\
\text { mAb clone ASO2 (Saalbach et al, 1996) }\end{array}$ & $\pm^{b}$ & ++ & +++ & 0 \\
\hline \multicolumn{5}{|l|}{ Epithelium } \\
\hline Cytokeratin, Sigma (Gigi-Leitner et al, 1986) & 0 & 0 & 0 & +++ \\
\hline
\end{tabular}

${ }^{a} 0$, no positive cells;,$\pm<10 \%$ of cells positive;,$+ 10 \%$ to $40 \%$ of cells positive;,$++ 40 \%$ to $70 \%$ of cells positive;,$+++ 70 \%$ to $90 \%$ of cells positive.

${ }^{b} \mathrm{~A}$ few cells in the smooth muscle layer stained intensely for ASO2, whereas most smooth muscle cells were negative. 
endothelium. Strong desmin and smooth muscle $\alpha$-actin staining was associated with both large vessels and microvessels. However, staining of $\alpha 1 \beta 1$ integrin and $\alpha$ - and $\gamma$-actin isoforms was much stronger in microvessels than in large vessels; the opposite was true for calponin and smooth muscle myosin, which were found predominantly in large vessels. High molecular weight-melanoma-associated antigen (HMW-MAA) was expressed weakly in large vessels but not at all in small vessels, and the PDGF- $\beta$ receptor was found in neither (Reuterdahl et al, 1993; Sundberg et al, 1993, 1996). Staining for procollagen Type I and prolyl-4-hydroxylase, markers for collagen synthesizing fibroblasts, was absent in both large and small vessels. ASO2, a marker for both pericytes and fibroblasts, was expressed in microvessels, in interstitial fibroblasts, and in a subpopulation of supporting cells present in larger vessels.

\section{Initial Isolation and Characterization of Dermal Pericytes}

Pericytes were isolated as previously described from explanted microvascular fragments (MVF) (Ivarsson et al, 1996; Sundberg et al, 1996). MVF are microscopic segments of blood vessels enveloped by both endothelium and pericytes. They were obtained from neonatal foreskins by enzymatic digestion and cultured on collagen Type I-coated dishes as previously described (Ivarsson et al, 1996; Sundberg et al, 1996). Contamination with single cells was minimal. After 2 days in culture, the majority of cells in MVFs stained strongly for pericyte/smooth muscle cell markers; however, most MVF also contained cells that stained with endothelial markers (CD31 and PAL-E) (Table 2). These cells were readily removed by subsequent treatment with $50 \mathrm{~mm}$ L-methyl leucine ester (Lee et al, 1998) (data not shown). Occasional cells in MVF stained for prolyl-4-hydroxylase, an enzyme involved in stabilizing the triple helix structure of fibrillar collagens (Höyhtyä et al, 1984), but not for procollagen Type 1 c-propeptide.

Also by 2 days, large cells with irregular edges had begun to migrate from microvascular fragments (periMVF, Table 2). These early migrating cells expressed the same profile of markers as did pericytes in neonatal human foreskin in situ, namely desmin, smooth muscle $\alpha$-actin, $\alpha 1 \beta 1$-integrin, $\alpha$ - and $\gamma$-actin isoforms, and myosin. In addition, however, they also expressed the pericyte activation markers HMW-MAA and PDGF- $\beta$ receptor but did not express procollagen Type I or prolyl-4-hydroxylase.

Subsequently, cells continued to migrate from MVF and formed a near confluent monolayer by $\sim 8$ days. At this time, PAL-E and CD31 staining cells were extremely rare and almost entirely confined to the MVF (Fig. 1a). Also, many cells within MVF and the majority of cells that remained in close proximity to MVF retained the same expression profile for pericyte markers as that observed in 2-day cultures (Table 2, Fig. 1, a to f).

By 8 days of culture, however, the predominant phenotype of cells that had migrated a distance from the vascular fragments had changed. These cells expressed lower levels of HMW-MAA (Fig. 1b), PDGF- $\beta$ receptor (not shown), and desmin, myosin, $\alpha 1 \beta 1$-integrin, and $\alpha$ - and $\beta$-actin; however, they continued to express smooth muscle $\alpha$-actin strongly (Table 2, Fig. 1). In addition, however, many of these cells now stained strongly for procollagen Type I (Fig. 1e), propyl-4 hydroxylase, and ASO2 (Table 2). Rare cells stained for cytokeratin, indicating the persistence of a few epithelial cells.

In summary, a migrating population of cultured cells that initially had expressed a phenotype consistent with that of dermal pericytes displayed a marked heterogeneity after 8 days in culture; ie, 10\% to $40 \%$ of cells that were within or in close proximity to the original MVF explants retained a marker profile similar to that of activated pericytes in situ, whereas the majority of cells that had migrated farther away from the explants had differentiated into collagen Type I-producing fibroblasts.

\section{Purification of Cells Having the In Situ Pericyte Phenotype from 8-Day Cultures}

To purify cells from 8-day cultures that continued to express the phenotype of pericytes in newborn foreskins, we made use of an immunoaffinity approach, exposing cultures to Dynabeads coated with the 3G5 $\lg \mathrm{M}$ antibody; this antibody specifically recognizes a surface ganglioside present on pericytes but not on smooth muscle cells or fibroblasts (Nayak et al, 1988). 3G5-coupled Dynabeads attached to individual cells primarily in and around vascular fragments, ie, in locations where cells had retained a pericyte phenotype as determined by immunohistochemical criteria (Fig. 1). Cells binding 3G5-coupled Dynabeads were then separated magnetically from other cells, replated on collagen Type I-coated coverslips, and allowed to grow in culture for 4 days, after which they were reanalyzed by immunohistochemistry (Table 2, Fig. 1 , $\mathrm{g}$ to I). The population of cells that had been purified with 3G5-coupled Dynabeads and recultured expressed the phenotype of activated pericytes, ie, a phenotype similar to that of cells that had initially migrated from MVF after 2 days of culture (Table 2, Fig. $1, g$ to I). Similar results were obtained when pericytes were purified with Dynabeads coupled to antibodies to PDGF- $\beta$ receptors or HMW-MAA (Table 2). Cells remaining after Dynabead selection were analyzed with the same panel of immunohistochemical markers and were found to express a predominately fibroblast phenotype (Table 2, 3G5-negative cells).

The pericyte phenotype of immunoaffinity-repurified cells remained stable in culture for up to 8 days, allowing for four to six cell doublings; thereafter, however, collagen Type I-producing cells once again appeared and became predominant by 12 days. Cells with a pericyte phenotype could once again be repurified from these cultures using Dynabeads coupled to antibodies against $3 G 5$, or, alternatively, antibodies against HMW-MAA or the PDGF- $\beta$ receptor (Table 2). 


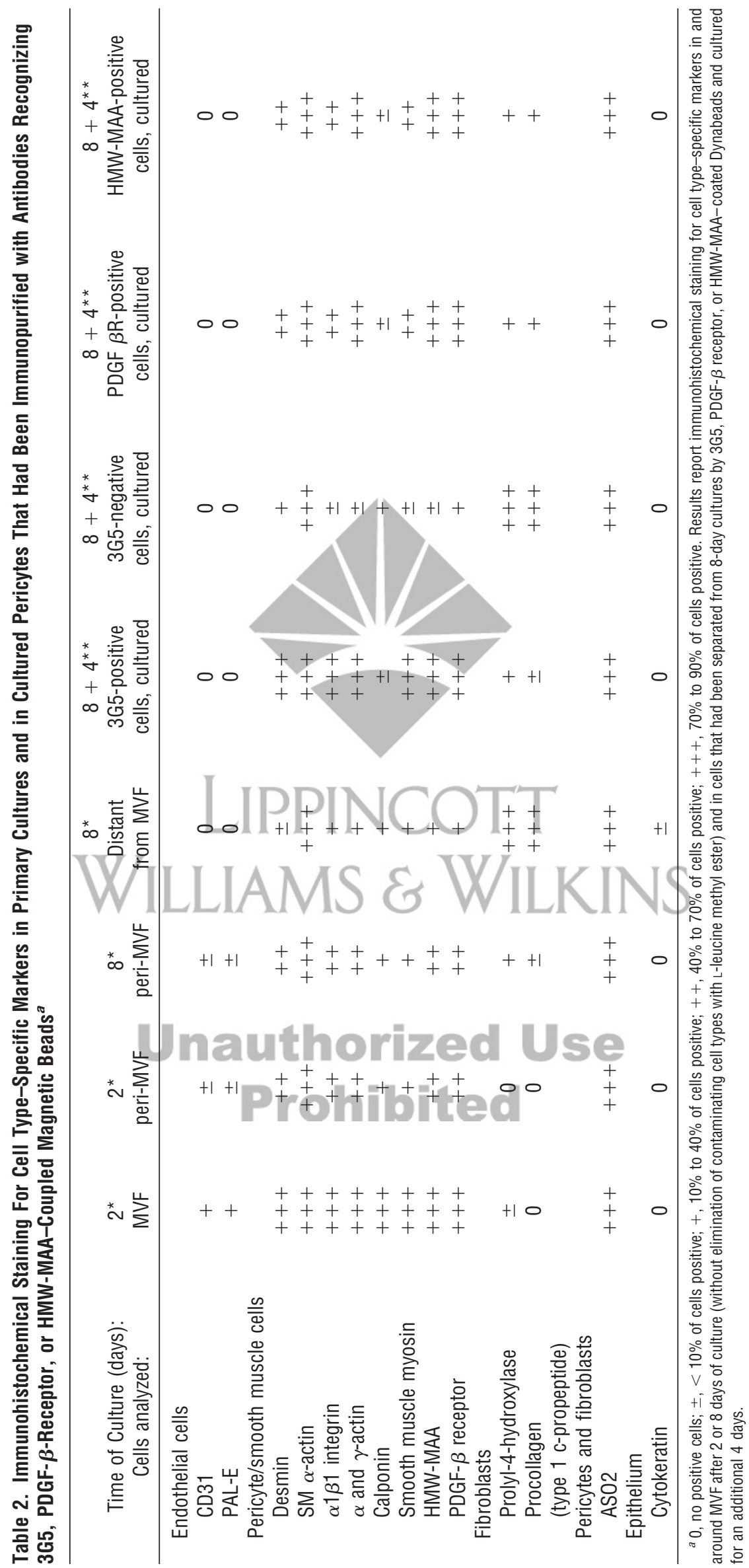




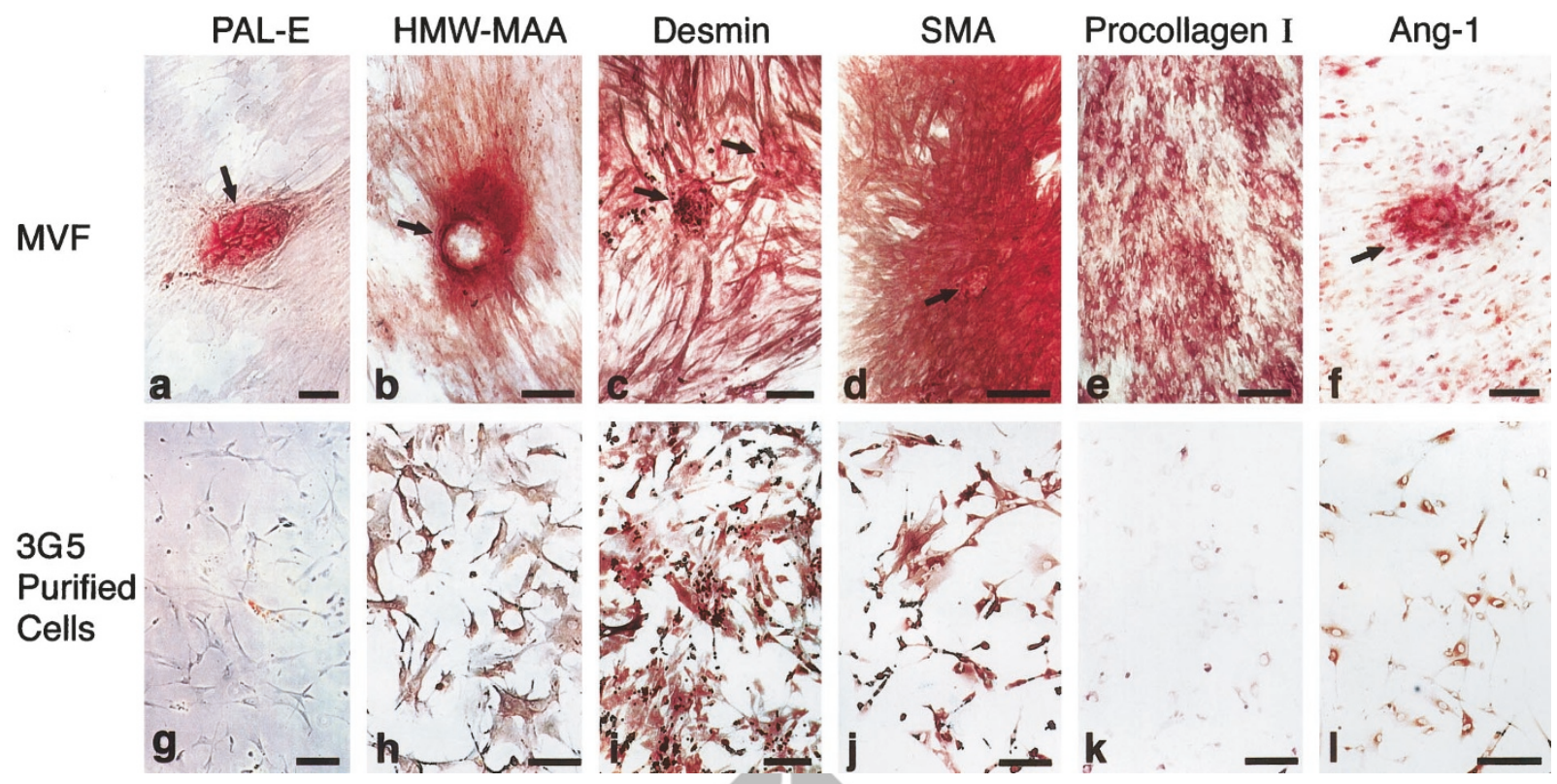

Figure 1.

Immunohistochemical expression of cell-type specific markers in cultured microvascular fragments (MVF) and immediately surrounding cells after 8 days in culture (a to f) and in cells repurified from 8-day MVF cultures with 3 G5 magnetic beads and cultured for an additional 6 days ( $g$ to I). a, PAL-E antibody stains endothelial cells remaining within a MVF; cells that have migrated from the fragment are PAL-E negative. $b$, Expression of the pericyte activation marker high molecular weight-melanoma-associated antigen (HMW-MAA) in cells at the periphery of a MVF and immediately adjacent to it; cells that have migrated a distance away from the MVF stain progressively less. c, Expression of desmin in cells within and in the immediate vicinity of two MVS, indicated by arrows. d, A majority of migrating cells express smooth muscle $\alpha$-actin. e, Procollagen Type I-positive and -negative cells are intermixed. f, Expression of angiopoietin-1 (Ang-1) in and immediately adjacent to a MVF. Nuclear staining in more peripheral cells is nonspecific. $g$ to I, 3G5-repurified cells are negative for PAL-E (g) and reacted weakly or not at all with antibodies to procollagen Type I (k); however, they are positive for HMW-MAA (h), desmin (i), smooth muscle $\alpha$-actin (j), and Ang-1 (I). Dark dots in i represent still-attached magnetic beads. Bar equals $50 \mu \mathrm{m}$.

The percent of cells that retained the activated pericyte phenotype and that could be recovered from mixed cultures remained relatively constant even after as many as eight serial passages in culture, ie, $21,6 \pm$ $3.8 \%$ of total cells (not shown); thus, even after eight passages, repurified cells could be cultured afresh and grown in sufficient quantities for biochemical and molecular biological analysis.

\section{Expression of Angiopoietins and Their Receptors in Cultured Newborn Foreskin Pericytes and Microvascular Endothelial Cells}

In situ hybridization was used to investigate the respective expression patterns of cultured dermal pericytes and microvascular endothelial cells. Cells purified using 3G5-coupled magnetic beads and having the pericyte phenotype expressed mRNA for Ang-1 (Fig. 2a) but not angiopoietin-2 (Ang-2) (Fig. 2b), angiopoietin-4 (not shown), Tie-1, Tie-2 (Fig. 2, c and d), or VEGFR-1 or VEGFR-2 (not shown). In contrast, dermal microvascular endothelial cells, isolated and cultured in parallel with pericytes, expressed Ang-2, Tie-1, Tie-2, VEGFR-1, and VEGFR-2 mRNAs (not shown). Expression of Ang-1 mRNA in pericytes (Fig. $3 \mathrm{~b})$ and expression of Ang-2 and the receptors Tie-1 and Tie-2 in endothelial cells were confirmed independently by Northern blot analysis (Fig. 3b). Expression of Ang-1 was also confirmed by immunoprecipitation of concentrated pericyte-conditioned medium and subsequent Western blotting. A weak band for Ang-1 protein was detectable in endothelial cells, reflecting an $\sim 5 \%$ residual contamination with pericytes (Fig. 3a). Immunohistochemical analysis of 8-day cultures also showed Ang-1 protein in cells within and immediately adjacent to MVF (Fig. 1f), as well as in cells purified from such cultures by means of 3G5-coupled Dynabeads (Fig. 11).

Expression of Ang-1 in the Granulation Tissue of Healing Wounds and in Later Stages of VPF/VEGF-Induced Angiogenesis

To determine whether our in vitro data had relevance in vivo, we investigated the expression of the angiopoietins and their Tie receptors in healing, fullthickness excisional wounds prepared on the dorsal flanks of guinea pigs (Fig. 4, a to i). At 7 days after wounding, Ang-1 was expressed in a subpopulation of cells in the granulation tissue. The Ang-1-positive cells were further characterized by double immunohistochemical staining and confocal microscopy. Ang-1 was found to be expressed in cells that commonly coexpressed HMW-MAA (Fig. 4, a to c), PDGF- $\beta$ receptors (not shown), and smooth muscle $\alpha$-actin (not shown) and were therefore identified as pericytes. In contrast, CD31-expressing cells (ie, endothelial cells) did not express Ang-1 (Fig. 4, d to f). However, some Ang-1-positive cells in the perivascular space did not stain for other pericyte markers, namely, HMW-MAA (Fig. 4, a to C), PDGF- $\beta$ receptors (not shown), or smooth muscle $\alpha$-actin (not shown), but did 

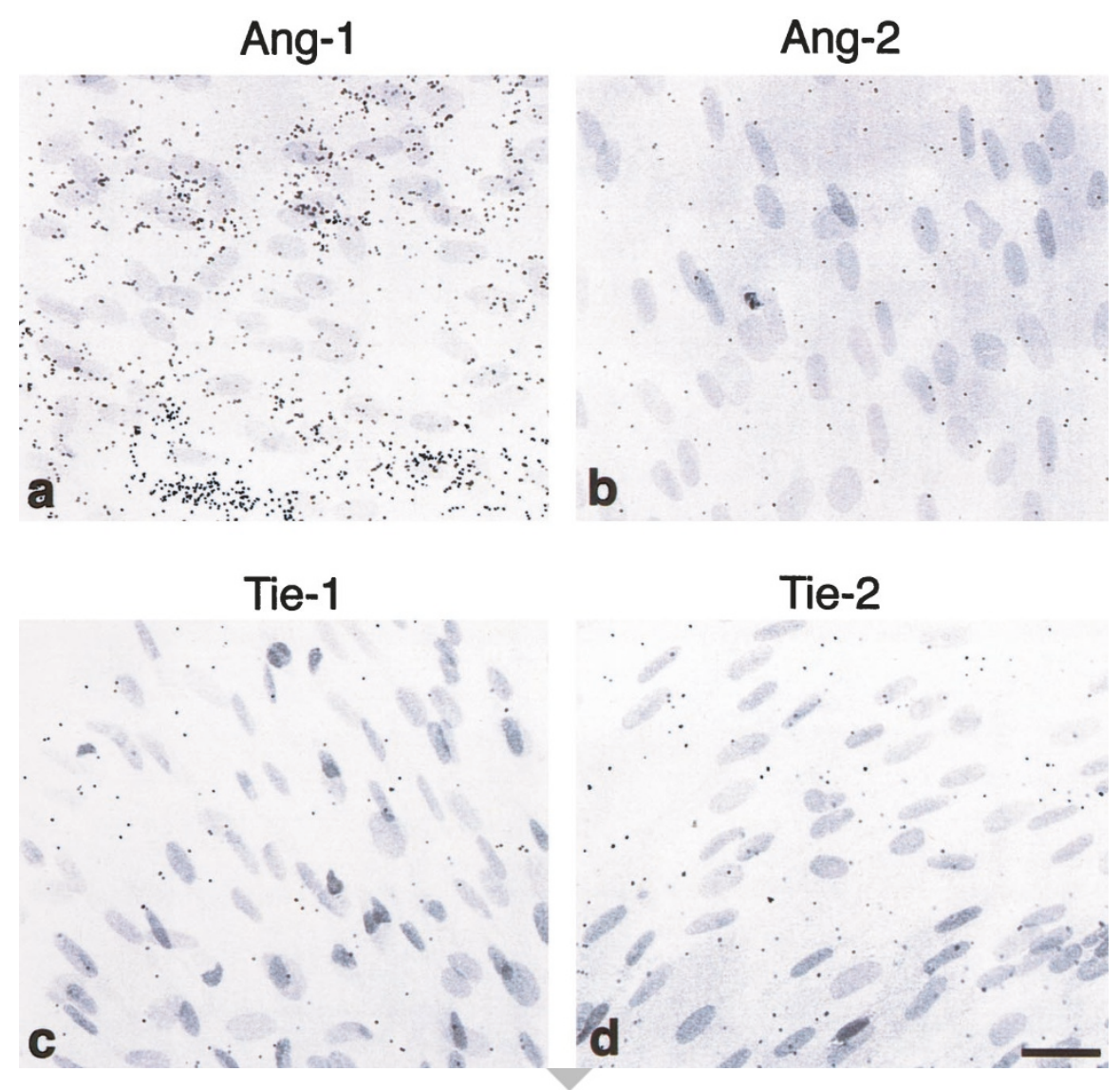

Figure 2.

In situ hybridization of cultured purified pericytes with antisense probes against the following: a, Ang-1; b, angiopoietin-2 (Ang-2); c, Tie-1; and d, Tie-2 mRNAs. Bar equals $25 \mu \mathrm{m}$.

stain for ASO2, a marker recognizing both pericytes and fibroblasts (Fig. 4, g to i), Conversely, the majority of ASO2-positive cells in the intervascular space did not stain with antibodies to Ang-1; cells that stained with both Ang-1 and ASO2 likely represent a minority subpopulation in the dermis, perhaps representing cells destined to associate with microvessels and become pericytes (Fig. 4, $\mathrm{g}$ to i).

We also investigated a second model of adult angiogenesis that induced by introduction of an adenoviral vector that had been engineered to express VPF/VEGF. Intradermal injection of adeno-vpf/vegf elicits an angiogenic response in skin and other tissues that is characterized by early formation of enlarged, thin-walled, pericyte-poor "mother" vessels; these subsequently evolve along several different pathways to form, among other outcomes, normal capillaries, large, muscular vessels, and glomeruloid bodies (Pettersson et al, 2000; Sundberg et al, 2001). Expression of Ang-1, Ang-2, the Tie receptors, and VPF/VEGF and its receptors were followed over time (Fig. 5). The mRNAs of VPF/VEGF and its receptors were detectable by in situ hybridization as early as 18 hours after adeno-vpf/vegf injection and reached peak intensity over the period of 3 to 10 days before declining on Day 14 and falling to very low levels by Day 28. By contrast, expression of Ang-1 mRNA became detectable only on Day 10 and persisted at plateau levels through Däy 14. Ang-2, Tie-1, and especially Tie-2 were expressed detectably in small blood vessels as early as Day 3 and reached peak levels by Day 10; their expression remained detectable on Day 14 and fell to low or undetectable levels by Day 28.

Immunohistochemistry was used to define Ang-1 expression in relation to developing blood vessels and glomeruloid bodies. Ang-1 was expressed in smooth muscle cells of large, muscular vessels (Fig. 5a) as well as in perivascular cells (Fig. 5, a to e) in 10-day lesions; Ang-1-positive cells were also distributed immediately perivascular to cells that expressed muscle cell markers (Fig. 5, a and c). A similar distribution of Ang-1positive cells was observed in and around microvessels (Fig. 5, g to i). CD31-reactive endothelium did not express Ang-1 in either muscular vessels or microvessels (Fig. 5, a, b, and d to f).

Neither Ang-1 mRNA nor protein was detected during the earliest stages of glomeruloid body formation (not shown). However, by 10 days after adenovpf/vegf infection, well-defined glomeruloid bodies had formed (Fig. 6, a to d) and included subpopulations of cells that expressed endothelial cell (CD31) and pericyte (NG2, the mouse equivalent of HMWMAA) markers. Ang-1 protein continued to be expressed by cells that enveloped endothelial cell-lined channels as glomeruloid bodies began to devolve into 


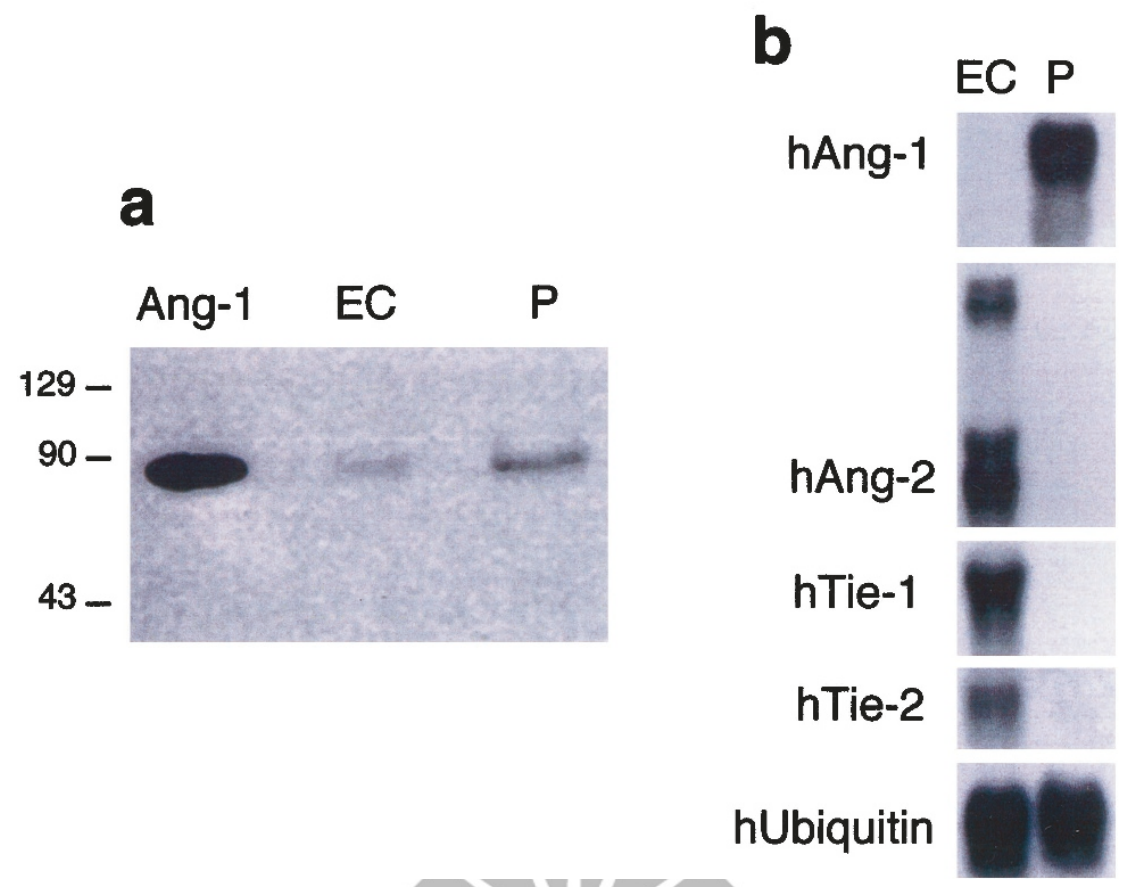

Figure 3.

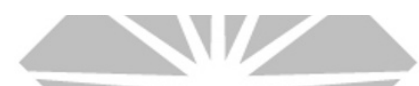

a, Cultured endothelial cells and pericytes repurified from primary cultures of MVFs were lysed, immunoprecipitated with a polyclonal antibody against Ang-1, and subjected to SDS-PAGE electrophoresis. Pericytes demonstrate a strong Ang-1 protein band at $\sim 90 \mathrm{kDa}$; endothelial cells show a much weaker band, reflecting $\sim 5 \%$ pericyte contamination without the L-leucine methyl ester step. Ang-1 is purified Ang-1 run as a standard. b, Northern blots of endothelial cell and pericyte RNAs probed with cDNAs recognizing human Ang-1, Ang-2, Tie-1, and Tie-2. Ubiquitin serves as a loading control. P = Pericytes; EC = Endothelial cells; $h=$ Human.

normal-appearing small vessels by Day 14 (Fig. 6, e to h).

\section{Discussion}

Pericytes have been difficult cells to study. They are readily identified in normal resting tissues by electron microscopy, based on their location in microvessels, envelopment by basal lamina, and the presence of numerous abluminal caveolae. However, the limited resolution of light microscopy often makes it difficult to distinguish pericytes with certainty from other vascular cells or from extravasating inflammatory cells in vivo, even with the help of immunohistochemistry or in situ hybridization. Furthermore, in pathology, intimate pericyte-endothelial cell relationships are commonly disturbed, contributing further to difficulty in pericyte identification. Although a number of pericyte surface markers are known, none is uniquely specific. For example, smooth muscle $\alpha$-actin is also expressed by smooth muscle cells and myofibroblasts (Gabbiani, 1992); also, pericyte expression of smooth muscle $\alpha$-actin varies considerably in different tissues and depends additionally on the extent of vessel activation (Schlingemann et al, 1991; Verbeek et al, 1994). Other markers such as HMW-MAA and the PDGF- $\beta$ receptor consistently recognize activated pericytes in situ but are not characteristic of pericytes in resting tissues. Finally, pericytes are plastic cells that do not maintain a constant, stable phenotype in culture, differentiating within a matter of days into collagen-expressing cells that more closely resemble fibroblasts. For this rea- son, cultured pericytes must be characterized frequently and certainly at each passage.

We have reported here a reliable and robust method for isolating, culturing, and characterizing pericytes from newborn foreskins. We chose this tissue because it has already been used as a valuable source of purified microvascular endothelial cells, thus making it possible in future experiments to coculture purified endothelial cells and pericytes from the same tissue. An important feature of our methodology is the use of MVF, rather than single isolated cells, as starting material for culture. MVF are basement membraneencompassed fragments comprised almost entirely of pericytes and endothelial cells. By beginning with MVF, we excluded from the start a majority of contaminating cells (eg, fibroblasts) that have the potential to overgrow pericytes in culture.

Our method differs from earlier reports (Challier et al, 1995; de la Rubia et al, 1992; D’Amore, 1992; He and Spiro, 1995; Helmbold et al, 2001; Hoying et al, 1996; Ivarsson et al, 1996; Lyons et al, 1994; Morse and Sidikaro, 1990; Sato et al, 1990; Schor et al, 1991; Schor and Schor, 1986; Shojaee et al, 1998; Sundberg and Rubin, 1996; Wisse et al, 1996) in several additional respects. One is the use of a second purification step involving the use of $3 G 5$ monoclonal antibodies linked to magnetic beads. Repurification with antibodies directed against two other surface markers of activated pericytes, PDGF- $\beta$ receptor and HMWMAA, worked equally well. We have also incorporated the important advance made by Lee et al (1998), 

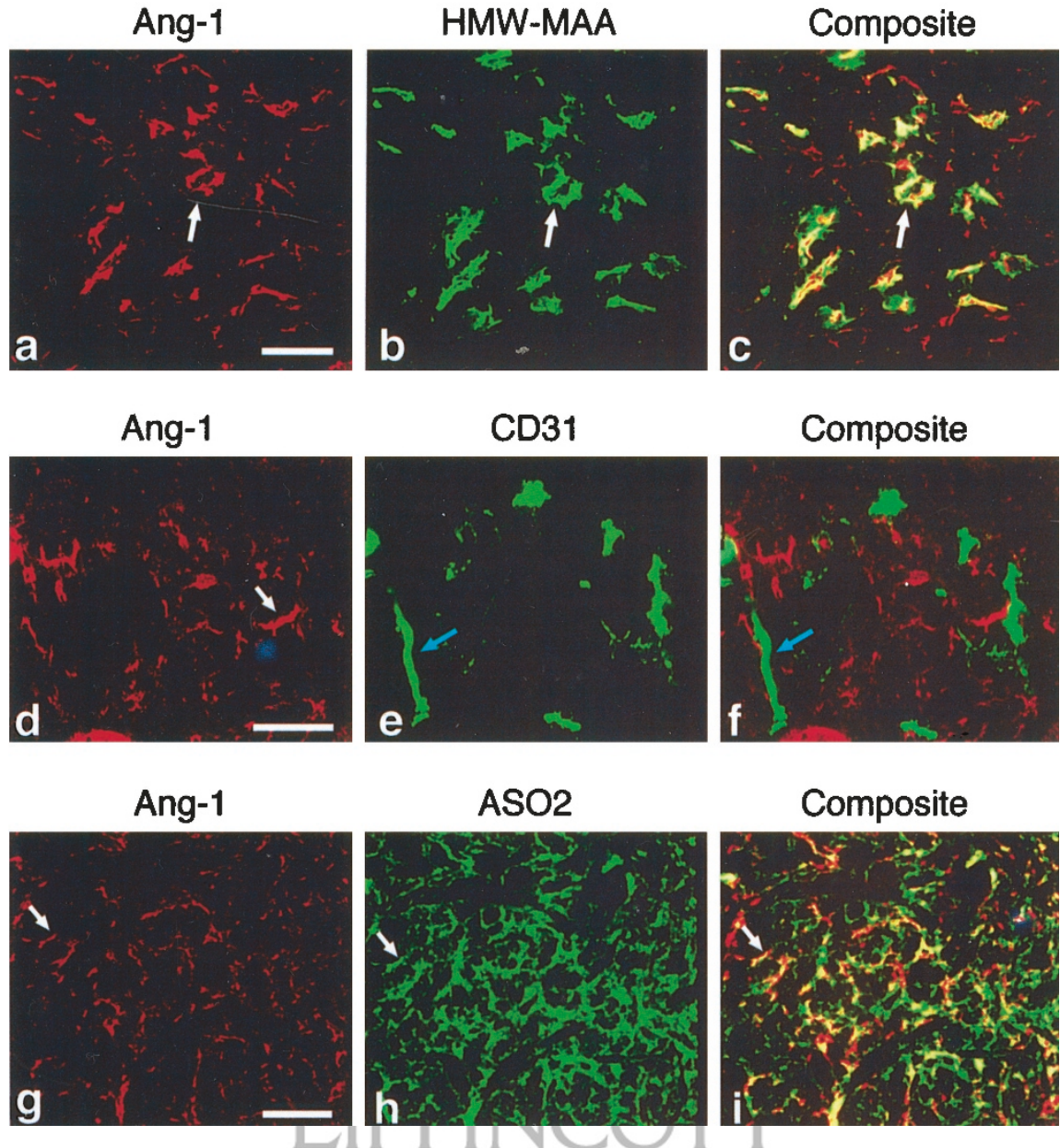

\section{Figure 4}

Immunofluorescence confocal microscopy of 7-day healing wounds in guinea pig flank skin, double-stained as indicated. a to c, Ang-1 (red) and HMW-MAA (green) expression colocalizes in perivascular cells (yellow color in composite). White arrow identifies a single cell (pericyte) followed in all three panels. $d$ to $f$, Ang- 1 (red) and CD31 (green) staining does not colocalize; however, cells expressing these markers lie in close proximity. $g$ to $i$, Ang-1 (red) and AS02 (green) staining exhibit partial colocalization (i, yellow color). Pericytes express Ang-1, whereas both pericytes and fibroblasts express AS02. The composite (i) indicates that Ang-1 expression is expressed on some but not on all cells staining with ASO2.

treating cultures with L-methyl leucine ester to selectively eliminate endothelial cell contaminants. Finally, and of considerable importance, is the use of a battery of antibodies to identify pericytes and to distinguish them at every stage of isolation and culture from other cell types, particularly fibroblasts, that share one or another pericyte marker. This is important because staining with only a single marker, such as smooth muscle $\alpha$-actin, cannot discriminate between pericytes that have retained their in vivo phenotype from those that have differentiated into collagen Type I-producing fibroblasts.

Despite extensive purification and repurification, cells expressing the characteristic pericyte phenotype evolve over time in culture into fibroblast-like cells that express Type-1 collagen. The mechanisms responsible for this transition are not known. However, a trivial explanation, namely that the cells expressing a fibroblast phenotype arose from a preexisting minority population of contaminating fibroblasts, seems unlikely. Prior evidence supports this conclusion (Ivarsson et al, 1996; Sundberg et al, 1996) and can be summarized as follows: (a) Microscopic sections of microvascular fragments prepared on MVF immediately after isolation demonstrated that the vast majority of cells were enveloped in basal lamina and stained with endothelial or pericyte markers. (b) Nearly all cells that migrated from MVF were HMW-MAA positive. (c) The great majority of dividing cells were pericytes as determined by dual labeling with Ki-67. (d) Expansion of a small population of contaminating fibroblasts was excluded by clonal analysis using lipophilic dyes. The possibility of fibroblast contamination has now been rendered even more unlikely by experiments reported here that cells that had been cultured after repurification with antibodies to $3 \mathrm{G} 5$ also generated fibroblastlike cells after a period of time. Nonetheless, we have been able to grow cells in culture for up to 8 days that retain the pericyte phenotype, providing these cells in sufficient numbers for biochemical and molecular characterization.

The purification studies presented here led to an additional important finding, namely, that cultured pericytes express Ang-1 as well as two other activation markers, HMW-MAA and PDGF- $\beta$ receptor, but not Ang-2 or the Tie-1 or Tie-2 receptors. By contrast, 

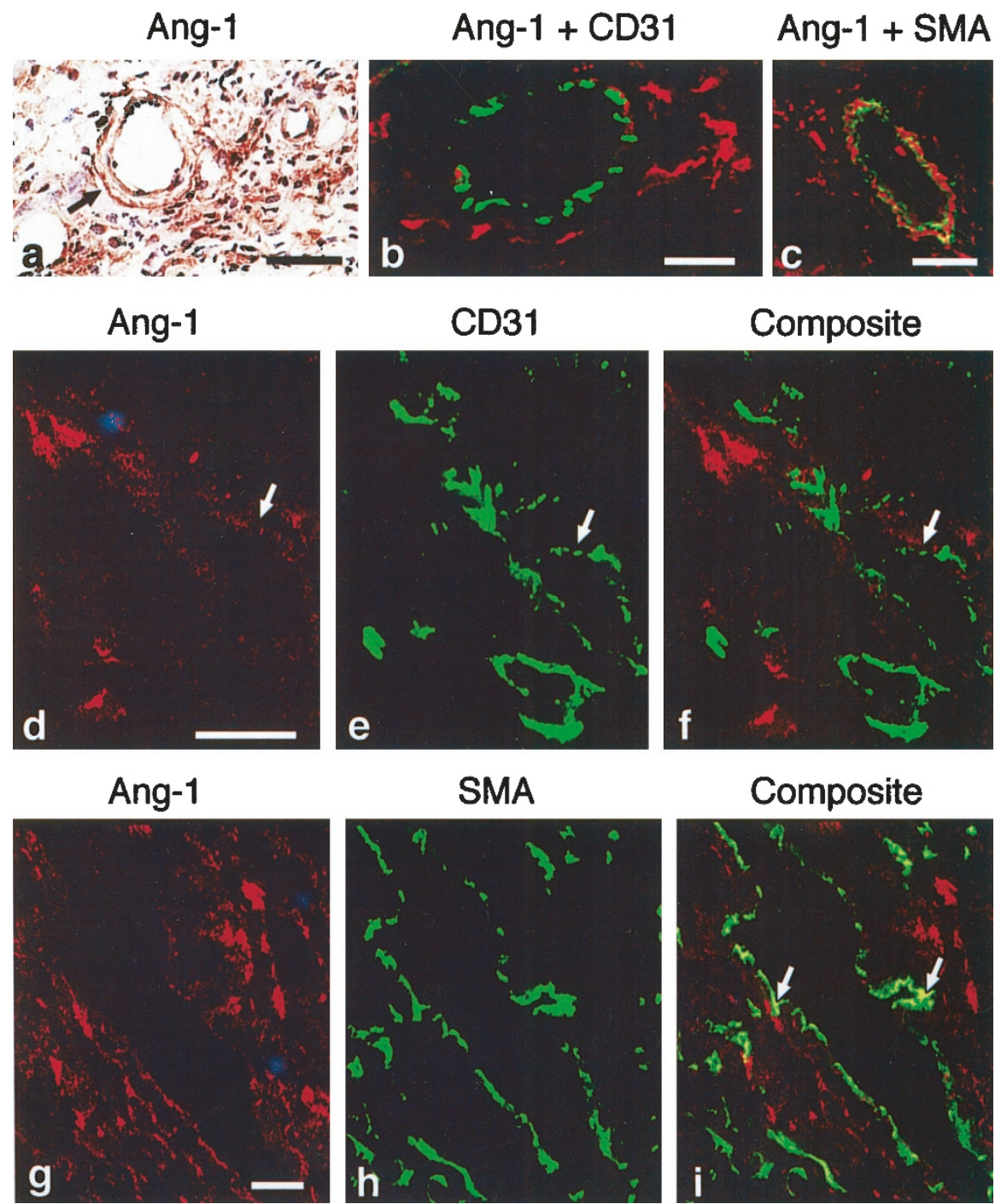

Figure 5 .

Ear skin from nude mice injected 10 days previously with adeno vpf/vegf analyzed by immunohistochemistry (a) and by confocal microscopy (b to i). a, Ang-1 is expressed in the smooth muscle layer (arrow) but not in the endothelium of vessels with a muscular coat. b and d to $\mathrm{f}$, As in healing wounds, Ang-1 (red) and CD31 (green) staining does not colocalize. $\mathrm{c}$ and $\mathrm{g}$ to $\mathrm{i}, \mathrm{Ang}-1$ (red) and smooth muscle $\alpha$-actin (green) staining colocalizes only in part (i, yellow). Ang-1 is expressed in pericytes as well as in cells in the perivascular space that are negative for smooth muscle $\alpha$-actin.

endothelial cells isolated from newborn foreskins express Ang-2 as well as the Tie- 1 and Tie- 2 receptors but not Ang-1. The idea that activated pericytes might express Ang-1 is not new but has been difficult to establish with certainty in vivo because of the difficulties of identifying individual cells as pericytes in tissue sections. A variety of cell types might, under different circumstances, be confused with pericytes as Ang-1expressing cells; these include dendritic cells, veil cells, mast cells, nerves, fibroblasts, activated tissue macrophages, leukocytes, and even endothelial cells. The reciprocal pattern of pericyte and endothelial cell expression demonstrated here is consistent with a paracrine interaction in which pericyte-secreted Ang-1 acts on endothelial cells through Tie receptors; however, the specific consequences of such an interaction are not as yet fully known. It has been suggested that Ang-1 is involved in the recruitment of supporting cells to the vasculature during embryogenesis (Yancopou- los et al, 2000). If this is the case, our results imply an indirect mechanism because pericytes, fibroblasts, etc. lack Tie receptors and therefore would not be expected to respond to Ang-1. Further studies will be needed to clarify this issue.

The functions of Ang-1 and its Tie-2 receptor have been the subject of much debate and speculation (Yancopoulos et al, 2000). Gene deletion studies in mice have suggested an important role for these molecules in vasculogenesis. Embryos lacking Ang-1 or Tie-2 die in utero and have similar phenotypes, ie, an apparently normal primary vasculature that fails to remodel and mature (Dumont et al, 1994; Sato et al, 1995; Suri et al, 1996). The defect in these animals is thought to reflect faulty interactions between endothelium, mesenchymal cells, and extracellular matrix, suggesting that Ang-1 interaction with Tie-2 is necessary for vascular stabilization. 


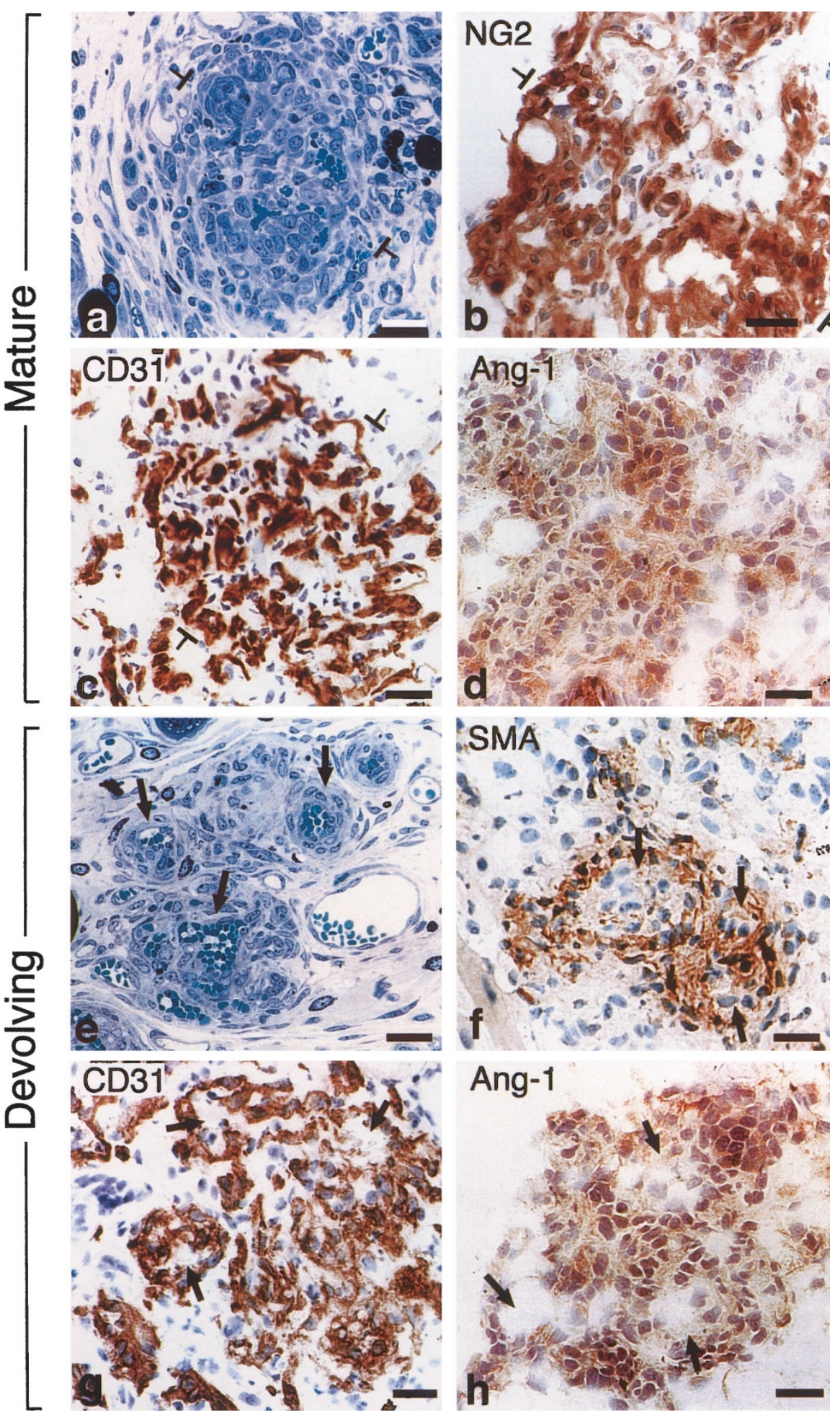

Figure 6.

Mature 10-day (a to d) and devolving 14-day (e to $\mathrm{h}$ ) glomeruloid bodies in the ear skin of nude mice after introduction of an adenoviral vector expressing vascular permeability factor/vascular endothelial growth factor (VPF/NEGF). a and e represent $1 \mu \mathrm{m}$-thick Giemsa-stained Epon sections. All other panels represent immunohistochemistry for NG-2, CD31, Ang-1, and smooth muscle $\alpha$-actin, as indicated. Brackets in a to c delimit glomeruloid bodies. Mature, 10-day glomeruloid bodies consist of masses of admixed endothelial cells and pericytes without discernible vessel structure. By 14 days, glomeruloid bodies have devolved into individually recognizable vascular structures with appropriate pericyte-endothelial cell orientation. These structures ultimately develop into mature functional vessels. Bar equals $25 \mu \mathrm{m}$.

To determine whether Ang-1 might have a similar role in stabilizing adult blood vessels, we investigated two well-defined models of angiogenesis, cutaneous wound healing and VPF/NEGF-induced angiogenesis. With double-immunofluorescence confocal microscopy it was possible in both models to identify peri- 
cytes with certainty and to distinguish them from endothelial cells and fibroblasts. In healing skin wounds, Ang-1 staining colocalized with that of HMWMAA and PDGF- $\beta$ receptors (both pericyte activation markers), with that of smooth muscle $\alpha$-actin, and in part with AS02 (a marker of both pericytes and fibroblasts), but not at all with CD31 (an endothelial cell marker). However, not all ASO2-positive cells expressed Ang-1. The subpopulation of cells that stained with both ASO2 and Ang-1 was localized to the tissue interstitium, distinctly apart from blood vessels. Therefore, Ang-1 apparently serves as a marker not only for pericytes but also for a subpopulation of fibroblasts. The precise nature and function of this subpopulation are not presently known. One possibility is that these cells represent fibroblasts that are pericyte precursors, ie, cells that will attach to blood vessels and become pericytes. This possibility is consistent with older literature suggesting that during the later phases of wound healing, pericytes are recruited from perivascular fibroblast-like cells (Díaz-Flores et al, 1992; Rhodin and Fujita, 1989). Another possibility is that they represent pericytes that have detached from blood vessels during the course of angiogenesis and have differentiated into fibroblasts, much as we have described here for pericytes in culture. Further studies will be required to distinguish between these possibilities.

Further evidence for an Ang-1/Tie-2 interaction in the maturation of adult microvessels was developed in studies of angiogenesis induced in ear skin with an adenoviral vector engineered to express VPF/VEGF. The details of the angiogenic response induced by VPF/VEGF have been described previously (Pettersson et al, 2000; Sundberg et al, 2001) but include the formation of glomeruloid bodies, structures that are comprised predominantly of endothelial cells and pericytes and that are common in certain malignant tumors. In glomeruloid bodies, cells expressing Ang-1, NG2, and CD31 were initially comingled. Ang-1-expressing cells colocalized in part with cells that expressed smooth muscle $\alpha$-actin (a marker for pericytes and smooth muscle cells) but not at all with CD31-expressing cells. As adenoviral vector driven expression of VPF/VEGF waned, glomeruloid bodies devolved into apparently normal mature microvessels. Accompanying this change, Ang-1 and smooth muscle $\alpha$-actin-reactive cells (putative pericytes) became oriented around CD31-positive cells (putative endothelium). Tie-1 mRNA was also transiently and concomitantly expressed. A ligand for Tie-1 has not been identified, and it is not known whether Ang-1 could serve as a ligand for the Tie-1 receptor during glomeruloid body formation and devolution. Taken together, these results and those obtained in healing wounds suggest that Ang-1 has a role in vessel maturation in adult tissues analogous to that reported in embryonic vasculogenesis (Dumont et al, 1994; Sato et al, 1995; Suri et al, 1996).

In summary, we have presented methods for isolating and growing pericytes in culture under conditions that allowed cell expansion sufficient for biochemical and molecular analyses while preserving a stable phenotype. The tools reported here should facilitate molecular studies of pericytes and be of use in further elucidating their roles in blood vessel formation. Our studies also provide definitive evidence that pericytes express Ang-1 but not Ang-2, Tie-1, or Tie-2, whereas endothelial cells derived from the same tissue, newborn skin, exhibit a reciprocal expression pattern. Finally, the timing of Ang-1 expression in healing skin wounds and in VPF/VEGF-induced angiogenesis favors the concept that the vascular stabilizing functions proposed for Ang-1 in developmental vasculogenesis (Dumont et al, 1994; Sato et al, 1995; Suri et al, 1996) can be extended to angiogenesis in adult animals.

\section{Materials and Methods}

\section{Isolation and Culture of Pericytes Derived from Human Foreskins}

Newborn human foreskins were obtained after routine circumcision and stored at $4^{\circ} \mathrm{C}$ in RPMI medium containing 20\% FCS, $200 \mu \mathrm{g} / \mathrm{ml}$ streptomycin-sulfate, $240 \mu \mathrm{g} / \mathrm{ml}$ penicillin G, $2 \mu \mathrm{g} / \mathrm{ml}$ amphotericin B, and 2 mM L-glutamine until further processing (Ivarsson et al, 1996; Sundberg et al, 1996). Foreskins were rinsed $3 \times$ in $70 \%$ ethanol, twice in PBS, $\mathrm{pH} 7.4$, and injected at multiple sites through a 27-g needle with a solution containing 2\% collagenase Type V (Sigma Chemical Company, St. Louis, Missouri) and buffer B (70 mM $\mathrm{NaCl}, 7 \mathrm{~mm} \mathrm{KCl}, 5 \mathrm{~mm} \mathrm{CaCl}$, 100 mm HEPES, pH 7.6, and $1.5 \%$ bovine serum albumin Fraction V) (Ivarsson et al, 1996; Sundberg et al, 1996). Tissues were then minced with ă razor blade, and the homogenate was diluted into -5 volumes of buffer $B$, resulting in a final concentration of $0.4 \%$ collagenase V. Homogenates were incubated at $37^{\circ} \mathrm{C}$ for 4 hours on a shaker, and the digest was then passed through a 130- $\mu$ m nylon filter to remove debris and larger vessel fragments. MVF were further dissociated by passage through a 21-gneedle and centrifuged at $200 \times g$ for 10 minutes. MVF pellets were then resuspended in PBS and centrifuged at $50 \times g$ for 10 minutes through a Percoll solution comprised of nine parts Percoll (Pharmacia, Uppsala, Sweden) and one part 10× PBS in $10 \mathrm{~mm}$ HEPES, pH 7.4. Pellets were again resuspended in buffer $B$ and incubated in 50-ml plastic tubes for 15 minutes at room temperature, allowing MVF to settle while leaving single cells in the supernatant. The pellet containing MVF was again resuspended and incubated in buffer $B$ for 15 minutes. MVF settled and were suspended in RPMI medium containing 20\% FCS (GIBCO BRL, Gaithersburg, Maryland) and were plated on 100-mm culture dishes coated with 10 $\mu \mathrm{g} / \mathrm{ml}$ bovine collagen Type I (Collagen Biomaterials, Palo Alto, California).

After 2 days in culture, cells identified as pericytes (for criteria, see Table 1) began to grow out from MVF. At this stage, endothelial and epithelial cells comprised $\sim 1 \%$ to $5 \%$ of the total cell population, and these were largely removed by incubating cultures 
with $50 \mathrm{~mm}$ L-leucine methyl ester (Sigma) in RPMI$20 \%$ FCS for 4 hours at $37^{\circ} \mathrm{C}$ (Lee et al, 1998). Cultures were then washed and allowed to recuperate for 2 days before replacing the medium.

To purify cells expressing a pericyte phenotype from mixed cell cultures, we made use of a monoclonal lgM antibody (3G5 hybridoma; American Type Culture Collection, Bethesda, Maryland) that recognizes a cell surface ganglioside present on pericytes but not on fibroblasts or smooth muscle cells (Nayak et al, 1988). The 3 G5 hybridoma was grown in suspension in Hybricell protein-free medium (Atlanta Biologicals, Atlanta, Georgia), and supernatants were collected, sterile filtered, and stored at $-20^{\circ} \mathrm{C}$. M450 Dynabeads $(200 \mu l)$ coupled to rat anti-mouse IgM (Dynal, Lake Success, New York) were added to $1 \mathrm{ml}$ of $3 \mathrm{G} 5$ hybridoma supernatant and incubated with gentle agitation at $4^{\circ} \mathrm{C}$ for 16 hours. Dynabeads were then washed four times in PBS and stored in medium containing $0.02 \%$ sodium azide. Dynabeads (30 to 50 $\mu \mathrm{l})$ were added to each $100-\mathrm{mm}$ dish of cultured cells and incubated on a rocker for 10 minutes, by which time one to two Dynabeads had attached to target cells. Pericytes were then detached by addition of $0.1 \%$ trypsin-EDTA (GIBCO BRL) for 5 to 10 minutes at $37^{\circ} \mathrm{C}$. Trypsin was neutralized with RPMI containing $10 \%$ FCS. Cells attached to Dynabeads were concentrated using a Dynal MPC-1 magnetic concentrator, sequentially washed in serum-free medium, magnetically concentrated $3 \times$, and plated on collagen Type I-coated plastic dishes (Becton Dickinson [BD], San Diego, California). Primary cultures of pericytes were grown on tissue culture-treated plastic dishes coated overnight $\left(4^{\circ} \mathrm{C}\right)$ with $10 \mu \mathrm{g} / \mathrm{ml}$ bovine collagen Type I, in RPMI medium containing 20\% FCS, 50 $\mu \mathrm{g} / \mathrm{ml}$ streptomycin-sulfate, $60 \mu \mathrm{g} / \mathrm{ml}$ penicillin $\mathrm{G}, 0.5$ $\mu \mathrm{g} / \mathrm{ml}$ amphotericin $\mathrm{B}$, and $2 \mathrm{~mm}$ L-glutamine.

\section{Isolation and Culture of Microvascular Endothelial Cells Derived from Human Foreskins}

Microvascular endothelial cells were isolated from human foreskins as previously described (Richard et al, 1998). Primary cultures of endothelial cells were grown on tissue culture-treated plastic dishes (BD) that had been coated overnight at $4^{\circ} \mathrm{C}$ with $10 \mu \mathrm{g} / \mathrm{ml}$ bovine collagen Type I and maintained in endothelial basal medium (Clontech, Palo Alto, California) containing 20\% FCS, $1 \mu \mathrm{g} / \mathrm{ml}$ hydrocortisone (Sigma), 50 mm N 2'-0-dibutyryladenosine 3'5'-cyclic monophosphate (Sigma), $50 \mu \mathrm{g} / \mathrm{ml}$ streptomycin-sulfate, 60 $\mu \mathrm{g} / \mathrm{ml}$ penicillin $\mathrm{G}, 0.5 \mu \mathrm{g} / \mathrm{ml}$ amphotericin $\mathrm{B}$, and 2 $\mathrm{mm}$ L-glutamine.

\section{Antibodies for Immunohistochemical Staining}

Most of the primary antibodies used for immunohistochemistry and their sources and specificities are listed in Table 1. The polyclonal antibody recognizing NG2 was from Chemicon (Temcula, California) (Levine and Nishiyama, 1996). One of us (MD) immunized rabbits with the 18-amino acid synthetic peptide QHREDGSLDFQRGWKEYC, corresponding to amino acid residues 328 to 344 of human Ang-1 (GenBank accession number U83508), using standard techniques. The antiserum was then affinity purified, and specificity for Ang-1 was confirmed by Western blotting, using recombinant human Ang-1 and Ang-2, kindly provided by Dr. G. Yancopoulos (Regeneron Pharmaceuticals, Tarrytown, New York). The mAb anti-mouse CD31 (Baldwin et al, 1994) was obtained from BD.

Normal rabbit, mouse, goat, swine and horse serum, and rat, rabbit, and mouse IgG were purchased from Sigma. The biotinylated horse anti-mouse antibody, the rabbit anti-rat Texas Red avidin D conjugate, fluoresceinated goat anti-rabbit, and rabbit anti-rat IgG were purchased from Vector Laboratories (Burlingame, California). Fluoresceinated goat anti-mouse IgG was purchased from BD, and the biotinylated swine anti-rabbit $(\mathrm{Fab})_{2}$ was from DAKO (Carpinteria, California). All antibodies were diluted in PBS containing $0.1 \%$ bovine serum albumin fraction $\mathrm{V}, 150 \mathrm{~mm}$ tranexamic acid, $20 \mu \mathrm{l} / \mathrm{ml}$ Trasylol (A6279), $1.8 \mathrm{~mm}$ EDTA, and $2 \mathrm{~mm}$ iodoacetic acid. Optimal concentrations were determined by serial dilution. All incubations were performed at room temperature.

\section{Immunohistochemical Staining of Cells}

Pericytes were grown on bovine collagen Type I-coated coverslips $(20 \mu \mathrm{g} / \mathrm{ml})$ in 24-well plates in RPMI (GIBCO BRL) containing 20\% FCS and antibiotics. Cells were washed twice in PBS and then fixed in fresh $4 \%$ paraformaldehyde for 10 minutes at room temperature. Coverslips were then rinsed in PBS, permeabilized in PBS supplemented with $0.1 \%$ Tween 20, rinsed, and then blocked in PBS supplemented with $0.1 \%$ BSA and $0.1 \mathrm{M}$ glycine. Coverslips were incubated with primary antibody for 1 hour, rinsed, and then incubated with the appropriate biotinylated secondary IgG and rinsed. Color was developed with the Vectastain ABC elite kit (Vector Laboratories) with diaminobenzidine as the peroxidase substrate. Coverslips where then mounted in crystal mount (Biomeda, Foster City, California).

\section{In Situ Hybridization of Cells and Tissue Sections}

In situ hybridization was performed with antisense single-stranded ${ }^{35} \mathrm{~S}$-labeled RNA probes as previously described (Brown et al, 2000). Corresponding sense probes served as controls. Ang-1 and Ang-2 and Tie plasmids were kindly provided by Regeneron Pharmaceuticals, Inc.

Purified pericytes were grown on Labtek 8-well chamber slides (BD) coated with bovine collagen Type I in RPMI medium containing 20\% FCS. Slides were fixed in 4\% paraformaldehyde in PBS, $\mathrm{pH} 7.4$, for 15 minutes and were stored in $70 \%$ alcohol at $4^{\circ} \mathrm{C}$. Tissues were fixed in RNAse-free $4 \%$ paraformaldehyde in PBS for 4 hours at $4^{\circ} \mathrm{C}$ and were transferred to $30 \%$ sucrose in $\mathrm{PBS}$ overnight at $4^{\circ} \mathrm{C}$ before 
embedding in optimal cutting temperature compound (Miles Diagnostics, Elkhart, Indiana).

\section{Northern Blot Hybridization}

Cultured cells were lysed in $4 \mathrm{M}$ guanidinium thiocyanate and RNA isolated as previously described (Claffey et al, 1992). Aliquots of RNA (10 $\mu \mathrm{g})$ were electrophoresed on $1 \%$ agarose gels and blotted onto Biotrans nylon membranes (ICN, Costa Mesa, California). Northern hybridization was performed with cDNA probes that had been labeled by random priming with $\left[\gamma^{32} \mathrm{P}\right] \mathrm{dCTP}$, using the multiprime DNA labeling system (Amersham, Paisley, United Kingdom) according to the manufacturer's instructions. The cDNA probes for human Ang-1, Ang-2, and for Tie-2 were obtained as described above. Ubiquitin or the ribosomeassociated protein cDNA, 36B4 (Masiakowski et al, 1982), was used to demonstrate equivalent RNA loading.

\section{Immunoprecipitation and Western Blotting}

Endothelial cells or pericytes were grown to near confluence on 100-mm tissue culture plastic dishes as described above. Conditioned medium was collected from cells grown without serum for 48 hours and was stored frozen at $-20^{\circ} \mathrm{C}$. Culture supernatants were concentrated with Centricon columns (Millipore, Bedford, Massachusetts), and protein concentrations were determined with the BioRad (Hercules, California) assay kit. Protein samples (7 mg each) were immunoprecipitated with rabbit anti-Ang-1 antibodies; recombinant human Ang-1 served as a positive control (Skobe et al, 2001).

\section{Wound Healing Experiments}

Incisional and excisional skin wounds were created on the dorsal flanks of 6- to 8-week-old Hartley guinea pigs with a scalpel or a 2-mm biopsy punch, respectively. Wounds were harvested at $1,3,7$, and 11 days. All studies were performed under hospital Institutional Review Board-approved protocols. Tissues were embedded in optimal cutting temperature compound and frozen in liquid nitrogen, sectioned, and subjected to standard immunohistochemical staining or doubleimmunofluorescence analysis by confocal (BioRad MRC 1024) microscopy.

\section{Animal Experiments with an Adenoviral Vector}

Experiments were performed in 4- to 6-week-old female immunodeficient nude mice as previously described (Pettersson et al, 2000). Adenoviral vectors $\left(2.5 \times 10^{8}\right.$ plaque forming units or dilutions thereof) engineered to express murine VPF/NEGF ${ }^{164}$ (adeno$\mathrm{vpf} /$ vegf) or LacZ (adeno-lacZ) were prepared as previously described (Pettersson et al, 2000) and were injected into mouse ear skin in a volume of $10 \mu \mathrm{l}$. Ears were collected from animals killed by $\mathrm{CO}_{2}$ narcosis at $0,4,18$, and 24 hours and at $3,7,10,14,21,28,35$, and 90 days. Normal mouse ears injected with vehicle (HBSS) served as controls.

Tissues were fixed in paraformaldehyde-glutaraldehyde and processed for 1- $\mu \mathrm{m}$ Epon sections as previously described (Dvorak et al, 1988). Alternatively, tissues were embedded in optimal cutting temperature compound and frozen in liquid nitrogen, sectioned, and subjected to standard immunohistochemical staining (Vectastain ABC elite kit; Vector Laboratories) or to double-immunofluorescence analysis with confocal microscopy (Sundberg et al, 2001).

\section{References}

Baldwin HS, Shen HM, Yan HC, Delisser HM, Chung A, Mickanin C, Trask T, Kirschbaum NE, Newman PJ, Albeda SM, and Buck CA (1994). Platelet endothelial cell adhesion molecule-1 (PECAM-1/CD31): Alternatively spliced, functionally distinct isoforms expressed during mammalian cardiovascular development. Development 120:2539-2553.

Benjamin LE, Hemo I, and Keshet E (1998). A plasticity window for blood vessel remodelling is defined by pericyte coverage of the preformed endothelial network and is regulated by PDGF-B and VEGF. Development 125:1591-1598.

Brown LF, Dezube BJ, Tognazzi K, Dvorak HF, and Yancopoulos GD (2000). Expression of Tie1, Tie2, and angiopoietins 1, 2, and 4 in Kaposi's sarcoma and cutaneous angiosarcoma. Am J Pathol 156:2179-2183.

Challier JC, Kacemi A, and Olive G (1995). Mixed culture of pericytes and endothelial cells from fetal microvessels of the human placenta. Cell Mol Biol 41:233-241.

Claffey KP, Wilkison WO, and Spiegelman BM (1992). Vascular endothelial growth factor: Regulation by cell differentiation and activated second messenger pathways. J Biol Chem 267:16317-16322.

Crosby JR, Tappan KA, Seifert RA, and Bowen-Pope DF (1999). Chimeric analysis reveals that fibroblasts and endothelial cells require platelet-derived growth factor receptor beta expression for participation in reactive connective tissue formation in adults but not during development. Am J Pathol 154:1315-1321.

D’Amore PA (1992). Capillary growth: A two-cell system. Semin Cancer Biol 3:49-56.

Davis S and Yancopoulos GD (1999). The angiopoietins: Yin and Yang in angiogenesis. Curr Top Microbiol Immunol 237:173-185.

de la Rubia G, Oliver FJ, Inoguchi T, and King GL (1992). Induction of resistance to endothelin-1's biochemical actions by elevated glucose levels in retinal pericytes. Diabetes 41:1533-1539.

Díaz-Flores L, Gutierrez R, and Varela H (1992). Behavior of postcapillary venule pericytes during postnatal angiogenesis. J Morphol 213:33-45.

Dumont DJ, Gradwohl G, Fong GH, Puri MC, Gertsenstein M, Auerbach A, and Breitman ML (1994). Dominant-negative and targeted null mutations in the endothelial receptor tyrosine kinase, tek, reveal a critical role in vasculogenesis of the embryo. Genes Dev 8:1897-1909.

Dvorak HF, Nagy JA, Dvorak JT, and Dvorak AM (1988). Identification and characterization of the blood vessels of 
solid tumors that are leaky to circulating macromolecules. Am J Pathol 133:95-109.

Gabbiani G (1992). The biology of the myofibroblast. Kidney Int 41:530-532.

Gale NW and Yancopoulos GD (1999). Growth factors acting via endothelial cell-specific receptor tyrosine kinases: VEGFs, angiopoietins, and ephrins in vascular development. Genes Dev 13:1055-1066.

Gigi-Leitner O, Geiger B, Levy Rivka N, and Czernobilsky B (1986). Cytokeratin expression in squamous metaplasia of the human cervix. Differentiation 31:191-205.

Gown AM, Tsukada T, and Ross R (1986). Human atherosclerosis. II. Immunocytochemical analysis of the cellular composition of human atherosclerotic lesions. Am J Pathol 125:191-207.

He Q and Spiro MJ (1995). Isolation of rat heart endothelial cells and pericytes: Evaluation of their role in the formation of extracellular matrix components. J Mol Cell Cardiol 27:11731183.

Heldin C-H, Bäckström G, Östman A, Hammacher A, Rönnstrand L, Rubin K, Nistér M, and Westermark B (1988). Binding of different dimeric forms of PDGF to human fibroblasts: Evidence for two separate receptor types. EMBO J 7:1387-1393.

Helmbold P, Nayak RC, Marsch WC, and Herman IM (2001). Isolation and in vitro characterization of human dermal microvascular pericytes. Microvasc Res 61:160-165.

Hemler ME (1990). VLA proteins in the integrin family: Structures, functions, and their role on leukocytes. Annu Rev Immunol 8:365-400.

Hirschi KK, Rohovsky SA, and D'Amore PA (1998). PDGF, TGF-beta, and heterotypic cell-cell interactions mediate endothelial cell-induced recruitment of $10 \mathrm{~T} 1 / 2$ cells and their differentiation to a smooth muscle fate. J Cell Biol 141:805814.

Höyhtyä M, Myllylä R, Piuva J, Kivirikko KI, and Tryggvason $\mathrm{K}$ (1984). Monoclonal antibodies to human prolyl 4-hydroxylase. Eur J Biochem 141:477-482.

Hoying JB, Boswell CA, and Williams SK (1996). Angiogenic potential of microvessel fragments established in threedimensional collagen gels. In Vitro Cell Dev Biol Anim 32: 409-419.

Ivarsson M, Sundberg C, Farrokhnia N, Pertoft H, Rubin K, and Gerdin B (1996). Recruitment of type I collagen producing cells from the microvasculature in vitro. Exp Cell Res 229:336-349.

Lee CS, Patton WF, Chung-Welch N, Chiang ET, Spofford $\mathrm{KH}$, and Shepro D (1998). Selective propagation of retinal pericytes in mixed microvascular cell cultures using L-leucine-methyl ester. BioTechniques 25:482-494.

Levine JM and Nishiyama A (1996). The NG2 chondroitin sulfate proteoglycan: A multifunctional proteoglycan associated with immature cells. Perspect Dev Neurobiol 3:245-259.

Lindahl P, Hellstrom M, Kalen M, and Betsholtz C (1998). Endothelial-perivascular cell signaling in vascular development: Lessons from knockout mice. Curr Opin Lipidol 9:407-411.

Longtine JA, Pinkus GS, Fujiwara K, and Corson JM (1985). Immunohistochemical localization of smooth muscle myosin in normal human tissues. J Histochem Cytochem 33:179184.

Lyons TJ, Li W, Wells-Knecht MC, and Jokl R (1994). Toxicity of mildly modified low-density lipoproteins to cultured retinal capillary endothelial cells and pericytes. Diabetes 43:10901095.

MacDonald JA, Broekelmann TJ, Matheke ML, Crouch E, Koo M, and Kuhn C (1986). A monoclonal antibody to the carboxyterminal domain of procollagen type I visualizes collagen-synthesizing fibroblasts: Detection of an altered fibroblast phenotype in lungs of patients with pulmonary fibrosis. J Clin Invest 78:1237-1244.

Masiakowski P, Breathnach R, Bloch J, Krust A, and Chambon $P$ (1982). Cloning of cDNA sequences of hormoneregulated genes from the MCF-7 human breast cancer cell line. Nucleic Acid Res 10:7895-7903.

Morse LS and Sidikaro Y (1990). Isolation and characterization of bovine choroidal microvessel endothelium and pericytes in culture. Curr Eye Res 9:631-642.

Natali PG, Imai K, Wilson BS, Bigotti A, Cavaliere R, Pellegrino MA, and Ferrone $S$ (1981). Structural properties and tissue distribution of the antigen recognized by the monoclonal antibody $653.40 S$ to human melanoma cells. J Natl Cancer Inst 67:591-601.

Nayak RC, Berman AB, George KL, Eisenbarth GS, and King GL (1988). A monoclonal antibody (3G5)-defined ganglioside antigen is expressed on the cell surface of microvascular pericytes. J Exp Med 167:1003-1015.

Nguyen LL and D'Amore PA (2001). Cellular interactions in vascular growth and differentiation. Int Rev Cytol 204:1-48.

Orlidge A and D'Amore PA (1987). Inhibition of capillary endothelial cell growth by pericytes and smooth muscle cells. J Cell Biol: 105:1455-1462.

Parums DV, Cordell JL, Micklem K, Heryet AR, Gatter KC, and Mason DY (1990). JC70: A new monoclonal antibody that detects vascular endothelium associated antigen on routinely processed tissue sections. J Clin Pathol 43:752757.

Pettersson A, Nagy JA, Brown LF, Sundberg C, Morgan E, Jungles S, Carter R, Krieger JE, Manseau EJ, Harvey VS, Eckelhoefer IA, Feng D, Dvorak AM, Mulligan RC, and Dvorak HF (2000). Heterogeneity of the angiogenic response induced in different normal adult tissues by vascular permeability factor/vascular endothelial growth factor. Lab Invest 80:99115.

Rajkumar VS, Sundberg C, Abraham DJ, Rubin K, and Black CM (1999). Activation of microvascular pericytes in autoimmune Raynaud's and systemic sclerosis. Arthritis Rheum 42:930-941.

Reuterdahl C, Sundberg C, Funa K, Rubin K, and Gerdin B (1993). Tissue localization of $\beta$-receptors for platelet-derived growth factor and platelet-derived growth factor B-chain during wound repair in humans. J Clin Invest 91:2065-2075.

Rhodin JAG (1968). Ultrastructure of mammalian venous capillaries, venules and small collecting veins. J Ultrastruct Res 25:452-500.

Rhodin JAG and Fujita H (1989). Capillary growth in the mesentry of normal young rats: Intravital video and electron microscope analysis. J Submicrosc Cytol Pathol 21:1-34. 
Richard L, Velasco P, and Detmar M (1998). A simple immunomagnetic protocol for the selective isolation and long-term culture of human dermal microvascular endothelial cells. Exp Cell Res 10:1-6.

Saalbach A, Aneregg U, Bruns M, Schnabel E, Herrmann K, and Haustein UF (1996). Novel fibroblast-specific monoclonal antibodies: Properties and specificities. J Invest Dermatol 106:1314-1319.

Sato TN, Tozawa Y, Deutsch U, Wolburg-Buchholz K, Fujiwara $Y$, Gendron-Maguire M, Gridley T, Wolburg H, Risau W, and Qin $Y$ (1995). Distinct roles of the receptor tyrosine kinases Tie-1 and Tie-2 in blood vessel formation. Nature 376:70-74.

Sato Y, Tsboi R, Lyons R, Moses H, and Rifkin DB (1990). Characterization of the activation of latent TGF beta by cocultures of endothelial cells and pericytes or smooth muscle cells: A self-regulating system. J Cell Biol 111:757763.

Schlingemann RO, Dingjan GM, Emeis JJ, Blok J, Warnaar SO, and Ruiter DJ (1985). Monoclonal antibody PAL-E specific for endothelium. Lab Invest 52:71-76.

Schlingemann RO, Rietveld FJR, Kwaspen F, van der Kerkhof FPC, de Waal R, and Ruiter DJ (1991). Differential expression of markers for endothelial cells, pericytes and basal lamina in the microvasculature of tumors and granulation tissue. Am J Pathol 138:1335-1347.

Schor AM, Canfield AE, Sloan P, and Schor SL (1991). Differentiation of pericytes in culture is accompanied by changes in the extracellular matrix. In Vitro Cell Dev Biol 27A:651-659.

Schor AM and Schor SL (1986). The isolation and culture of endothelial cells and pericytes from the bovine retinal microvasculature: A comparative study with large vessel vascular cells. Microvasc Res 32:21-38.

Shojaee N, Patton WF, Chung-Welch N, Su Q, Hechtman HB, and Shepro D (1998). Expression and subcellular distribution of filamin isotypes in endothelial cells and pericytes. Electrophoresis 19:323-332.

Skalli O, Ropraz P, Trzeciak A, Benzonona G, Gilessen D, and Gabbiani G (1986). A monoclonal antibody against alpha smooth muscle actin: A new probe for smooth muscle differentiation. J Cell Biol 103:2787-2796.

Skobe M, Hawighorst T, Jackson DG, Prevo R, Janes L, Velasco P, Riccardi L, Alitalo K, Claffey K, and Detmar M (2001). Induction of tumor lymphangiogenesis by VEGF-C promotes breast cancer metastasis. Nat Med 7:192-198.
Sundberg C, Branting M, Gerdin B, and Rubin K (1997). Tumor cell and connective tissue cell interactions in human colorectal adenocarcinoma: Transfer of platelet-derived growth factor AB/BB to stromal cells. Am J Pathol 151:479492.

Sundberg C, Ivarsson M, Gerdin B, and Rubin K (1996). Pericytes as collagen producing cells in excessive dermal scarring. Lab Invest 74:452-466.

Sundberg C, Ljungström M, Lindmark G, Gerdin B, and Rubin K (1993). Microvascular pericytes express plateletderived growth factor $\beta$-receptors in human healing wounds and colorectal adenocarcinoma. Am J Pathol 143:13771388.

Sundberg C, Nagy JA, Brown LF, Feng D, Eckelhoefer IA, Manseau EJ, Dvorak AM, and Dvorak HF (2001). Glomeruloid microvascular proliferation follows adenoviral vascular permeability factor/vascular endothelial growth factor-164 gene delivery. Am J Pathol 158:1145-1160.

Sundberg C and Rubin K (1996). Stimulation of $\beta 1$ integrins on fibroblasts induces PDGF independent tyrosine phosphorylation of PDGF $\beta$-receptors. J Cell Biol 132:741-752.

Suri C, Jones PF, Patan S, Bartunkova S, Maisonpierre PC, Davis S, Sato TN, and Yancopoulos GD (1996). Requisite role of angiopoietin-1, a ligand for the TIE2 receptor, during embryonic angiogenesis [see comments]. Cell 87:11711180.

Van Muijen GN, Ruiter DJ, and Warnaar SO (1987). Coexpression of intermediate filament polypeptides in human fetal and adult tissues. Lab Invest 57:359-369.

Verbeek MM, Otte-Höller I, Wesseling P, Ruiter DJ, and de Waal RMW (1994). Induction of $\alpha$-smooth muscle actin expression in cultured human brain pericytes by transforming growth factor- $\beta 1$. Am J Pathol 144:372-382.

Wisse E, Braet F, Luo D, De Zanger R, Jans D, Crabbe E, and Vermoesen A (1996). Structure and function of sinusoidal lining cells in the liver. Toxicol Pathol 24:100-111.

Yancopoulos GD, Davis S, Gale NW, Rudge JS, Wiegand SJ, and Holash J (2000). Vascular-specific growth factors and blood vessel formation. Nature 407:242-248. 